\title{
Environment and plastics : A review on greener routes for plastic bottle (PET) waste management through recycling processes
}

Swati Singh

CORRESPONDING AUTHOR : Swati Singh, Department of Applied Science, Sir Chhotu Ram Institute of Engineering and Technology, Chaudhary Charan Singh University, Meerut (U.P.) India

Email: swatijanmajay@yahoo.com

Received : 13.10.2020; Accepted : 21.11 .2020

\section{Summary}

Many research papers have been contributed by several authors for making polyethylene terephthalate (PET) waste recycling economically and ecologically more viable as it creates environmental hazards when disposed off after its short term use. Recycling of PET waste was started in last two decades. Most of the authors are devoting their time in getting economically viable solution for development of methods based on either mechanical or chemical recycling. Some success has been obtained in development of chemical recycling methods which provides value added products from PET waste. In this study the operating conditions and mechanism of various recycling processes available for the recycling of polyethylene terephthalate (PET) waste are reported and described.

Key words : PET, Waste management, Recycling

How to cite this article : Singh, Swati (2020). Environment and plastics: A review on greener routes for plastic bottle (PET) waste management through recycling processes. Asian J. Soil Sci., 15(2): 105-110: DOI : 10.15740/HAS/AJSS/15.2/105-110. Copyright@2020: Hind Agri-Horticultural Society. 